\title{
A flash flood hazard assessment in dry valleys (northern France) by cellular automata modelling
}

\author{
Johnny Douvinet $\cdot$ Marco J. Van De Wiel • Daniel Delahaye • \\ Etienne Cossart
}

Received: 17 October 2013/ Accepted: 6 October 2014/Published online: 31 October 2014

(C) The Author(s) 2014. This article is published with open access at Springerlink.com

\begin{abstract}
This paper presents an application of a cellular automaton-based run-off model (RUICELLS) to a series of small dry valleys in the Seine-Maritime department, northern France, to better assess their susceptibility to flash flood. These muddy floods shortly follow high rainfall (50-100 $\mathrm{mm}$ in less than $6 \mathrm{~h})$ and occur in very small areas $\left(<20 \mathrm{~km}^{2}\right)$. A surge generally rushes down through the main valley just a few minutes after rains have peaked. Previous events ( $n=69$, in the period 1983-2005) have occasionally threatened human lives and have caused significant damage to property and infrastructure. Nonetheless, given the variation among the valleys and the infrequency of events, these floods have not been numerous enough to permit a statistical analysis. Instead, we numerically simulate the possible future flash floods using RUICELLS, a cellular automaton model driven by a set of three deterministic hydrological rules. Simulations have been conducted for 148 basins, each subject to 16 different rainfall scenarios (2.368 simulations in total) to (1) estimate the peak flow discharges $(Q)$, the specific peak flows $\left(Q_{s}\right)$, and the lag times (T) of the flash floods and (2) detect the critical rainfall intensities that would trigger
\end{abstract}

\footnotetext{
J. Douvinet $(\bowtie)$

UMR ESPACE 7300 CNRS, University of Avignon and Pays du Vaucluse, 74 rue Louis Pasteur, 84029 Avignon Cedex 1, France

e-mail: johnny.douvinet@univ-avignon.fr

M. J. Van De Wiel

Department of Geography, Univeristy of Western Ontario, 1151 Richmond Street, London, ON, Canada

e-mail: mvandew3@uwo.ca

D. Delahaye

UMR LETG 6554 CNRS - Geophen, University of Caen Basse-Normandie, Esplanade de la Paix, Bâtiment Accueil, 14032 Caen Cedex, France

e-mail: daniel.delahaye@unicaen.fr

E. Cossart

UMR PRODIG 8586 CNRS, University of Paris 1 Panthéon-Sorbonne, 2 rue Valette, 75005 Paris, France

e-mail: etienne.cossart@univ-paris1.fr
} 
warnings and increased vigilance. Our simulations indicate that the number of basins susceptible to flash flooding greatly increases with the higher rainfall intensity, the distribution of sensitive crops (sugar beet, corn, maize, and flax) and the basin morphology. Several small basins could also induce by convergence a bigger flood in the downstream humid valleys. The location of the highest simulated discharges is aligned with observed events, and this comparison provides an evaluation of the modelling performance and of the credibility of the results.

Keywords Flash flood - Dry valleys - Susceptibility assessment $\cdot$ Northern France

\section{Introduction}

Flash floods in northern France (Masson 1987; Devaud 1995; Merle et al. 2001; ArnaudFassetta et al. 2011) induce serious risk conditions on populated outlets, especially in the Seine-Maritime department (Delahaye et al. 2001; Douvinet 2008, 2014; Douvinet et al. 2013). These hazards are generated shortly after rains ranging from 50 to $100 \mathrm{~mm}$ in less than $6 \mathrm{~h}$ and occur in small dry valleys $\left(<20 \mathrm{~km}^{2}\right)$. Such flash flood presents distinct features: a violent onset, a rapid rising time, and a surge rushing down just a few minutes after rainfall peaked. Previous floods have occasionally threatened human lives (11 persons died over the period 1983-2005 in this department), and caused significant damage to property and infrastructure (ranging from 0.05 to 14 million Euro for the 1997, June 16th event). The hydrological and geomorphological characteristics are quite similar to others occurring in other sedimentary areas, in western France (Auzet et al. 1995) or in Flanders (Evrard et al. 2007) for example, but are notably different to French Mediterranean floods. The latter occur in basins with higher slope gradients, larger basin area (ranging from 50 to $300 \mathrm{~km}^{2}$ ) and are typically associated with higher rainfall intensities ( et al. 2001; Collier and Fox 2003; Reid 2004; Barrera et al. 2006; Ruin et al. 2007; Ortega and Heydt 2009; Gaume et al. 2009; Morin et al. 2009; Marchi et al. 2010).

Predicting the time of occurrence and the intensity of northern flash floods remains difficult at larger scales for several reasons: measurements and field-based experimentations are rarely conducted in small dry valleys; these phenomena are insufficiently documented and remain difficult to monitor as they produce destructive effects to measuring devices; the rarity of events and the long recurrence intervals hamper statistical analysis and calibration of models (Ferraris et al. 2002); the short distances between source areas (run-off production) and risk zones (i.e. settlements) frequently surprise inhabitants in a few minutes; changes in velocity, roughness, and water height introduce uncertainties in the estimation of peaks discharge (Gaume et al. 2009; Douvinet and Delahaye 2010) and strongly hamper the classical hydrological approaches (Anquetin et al. 2009; Lumbroso and Gaume 2012).

Because of the statistical models' reliance on extensive inventories of location-specific past events, they are less transferable between different areas. Furthermore, they only implicitly represent the impacts of processes, rather than the processes themselves (Kappes et al. 2011). Conversely, the physically based models, including cellular automaton (CA) models, consider common physical characteristics of salient processes and are more readily transferable between sites (Coulthard and Van De Wiel 2006; Ménard and Marceau 2006; Van de Wiel et al. 2007). Consequently, we propose applying a CA model, i.e. RUICELLS 
(Delahaye et al. 2001; Douvinet et al. 2013), to anticipate the spatial occurrence and areas at risk. The RUICELLS model requires fewer parameters than most other physically based models, as distributed (or semi-distributed) hydrological models or soil erosion models (SEMs). Although a few similarities exist between these models (e.g. SEMs need to determine surface run-off before they can calculate soil erosion), the main difficulties are the greater number of environmental factors required (Jetten et al. 1996; Nearing et al. 2005).

By means of a combination of environmental parameters, chosen on the basis of previous experiences, three variables (peak flow, specific flow, and lag time) were calculated for 16 rainfall scenarios on 148 basins (2,386 simulations in total). The methodology applied here simplifies rainfall inputs to 16 rainfall scenarios. The reason for this is twofold. First, even though the recent efforts in meteorological observations provide relevant details on timing and location of convective storms (Collier and Fox 2003), the existing models (e.g. AROME or PANTHERE) do not yet predict rainfall intensities either with sufficient precision at fine scales $\left(<10 \mathrm{~km}^{2}\right)$ or with sufficient advance warning $(1 \mathrm{~h})$. Second, this simplified rainfall approach allows us to control the end-to-end simulation process (Fonstad 2006), measuring the transformation of input to output data, testing the sensitivity of basins to initial conditions, and defining their reactivity to different rainfalls with which we cannot experiment in reality.

\section{Study sites}

An earlier study of 189 basins affected by flash floods over the period 1983-2005 in northern France (Douvinet 2008) allowed the identification of a certain number of properties that make basins susceptible to flash floods. Extrapolation of such criteria over the department of Seine-Maritime allows the identification of 148 basins with similar features (Fig. 1). Firstly, all these basins are inhabited at their outlet and thus potentially exposed to flash flooding hazards. Consequently, the simulations may improve knowledge on risk and critical rains, which can be used to trigger increased vigilance or alert warnings as soon as possible. Secondly, the basins are small in size $\left(<20 \mathrm{~km}^{2}\right)$, including 67 very small basins $\left(<5 \mathrm{~km}^{2}\right.$ ), 54 basins of medium size (from 5 to $9 \mathrm{~km}^{2}$ ) and 30 "bigger" basins (from 9 to $20 \mathrm{~km}^{2}$ ). They also include the steepest departmental slopes (ranging from 2 to $15 \%$ ) and long profiles (up to $3 \%$ ) and are always connected to major humid valleys in short distances $(<3 \mathrm{~km})$ creating an order gap in the Strahler (1952) network ordination (Douvinet et al. 2013). This explains why hydrological responses $(<2 \mathrm{~h})$ and meteorological conditions at fine scale $(<1 \mathrm{~km})$ are crucial, but also why anticipating events remain difficult (Douvinet et al. 2013). Thirdly, the average percentage of grass, forests, and/or cultivated areas at basin scale varies strongly (Table 1). The spatial interactions between the run-off production (from cultivated areas) and water flow pathways (influenced by the morphology) are more important than the overall land-use percentages. As a basic example, the basin of St-Martin-de-Boscherville (with only $22 \%$ of cultivated areas) induced the most dramatic event (4 victims on June 16th, 1997) over the period 1983-2005. Fourthly, all the basins have common morphostructural features, since they all belong to the Parisian Basin. The landscapes consist of successive sub-horizontal to slightly undulating plates (Mathieu et al. 1997) incised by dry valleys, which are inherited from the Quaternary periglacial periods (Lahousse et al. 2003; Larue 2005). Finally, the dominant soils (i.e. luvisols) are characterized by small rates of organic matter $(<2 \%)$ and clay $(<15 \%)$, but high contents of silt $(>70 \%)$. This soil component renders the soils highly vulnerable to erosion in spring and summer. The surface degradation under raindrop 
impact induces a strong reduction of infiltration capacities, and the progressive disappearance of soil roughness concentrates run-off water. This explains why the soil erosion is extensively studied in this region, where the land-use dynamics and agricultural practices increase run-off production (Souchère et al. 2005).

\section{Materials and methods}

\subsection{CA background for hydrological modelling}

Cellular automaton models increasingly contribute to hydrological or geomorphological studies over the last decade (e.g. Ménard and Marceau 2006; Coulthard et al. 2007; Van de Wiel et al. 2007, 2011). In these dynamic models, the global properties arise from the local and spatial interactions of cellular entities (Wolfram 2002; Fonstad 2006). A lattice on which each cell possesses its own state characterizes these models. The time is discrete and the state of cells updated through the application of a set of predefined rules (Phipps and Langlois 1997). These rules, either expert-based, deterministic or probabilistic, dictate how the cells interact with their neighbors. The CA modelling approach is decades old, introduced by Von Neumann in 1951 (Gardner 1970), made famous by Conway's Game of Life (1970) and has supported an array of advances in many fields since the 1980s in physics, mathematics, chemistry, and ecology, and since the mid-1990s also in geomorphology (Douvinet et al. 2013). For example, the CA models have been used to study aeolian ripples (Anderson 1990), forest fires (Clarke et al. 1994), debris flows (Di Gregorio et al. 1998), debris-laden floods (Bursik et al. 2003), lava dynamics (Avolio et al. 2006), channel meandering (Coulthard and Van de Wiel 2006), the evolution of coasts (Dearing et al. 2005), and the response modelling of river systems (Van de Wiel et al. 2011) among others.

Murray and Paola (1994)'s braided river model was the first CA including hydrological and geomorphological processes, although their representations of river processes did not include explicit time and real physical scaling (Parsons and Fonstad 2007). Thomas and Nicholas (2002) extended the Murray-Paola model to simulate more realistic flow dynamics in braided river systems. Other water flow models have been developed, e.g. to simulate the growth of small rills in response to hillslope erosion (Favis-Mortlock 1998), to measure soil erosion at microscopic scales in SoDa (Valette et al. 2006), or to simulate basin responses using a wave approximation for in-channel flows (De Roo et al. 1996). Coulthard et al. (2007) and Van de Wiel et al. (2007) recently introduce a gradually varied $\mathrm{CA}$ for catchment evolution modelling that includes sediment transport dynamics. A more recent version (Coulthard et al. 2013) includes unsteady catchment hydrology. Although all these models differ considerably in their aims and implementation details, they share a common conceptual design in which a link is established between topographic variables, such as the elevation and its derivative, and hydraulic variables, such as water fluxes and flow velocity. The rules of each CA model describe the precise nature of that link.

Cellular automaton models can also be linked with smoothed particle approaches (e.g. Drogoul 1993) to better assess generic dynamics or hydrological fluxes. In recent years, agent-based modelling (ABM) has been tested in hydrology and geomorphology after first initiatives in ecology, sociology, or human geography. These models may provide alternative approach to CA modelling. For example, CATCHSCAPE allows simulating the hydrological system with its distributed water balance or to irrigate schemes management, crop and vegetation dynamics (Bécu et al. 2003). ABMs can be used in alluvial plains 


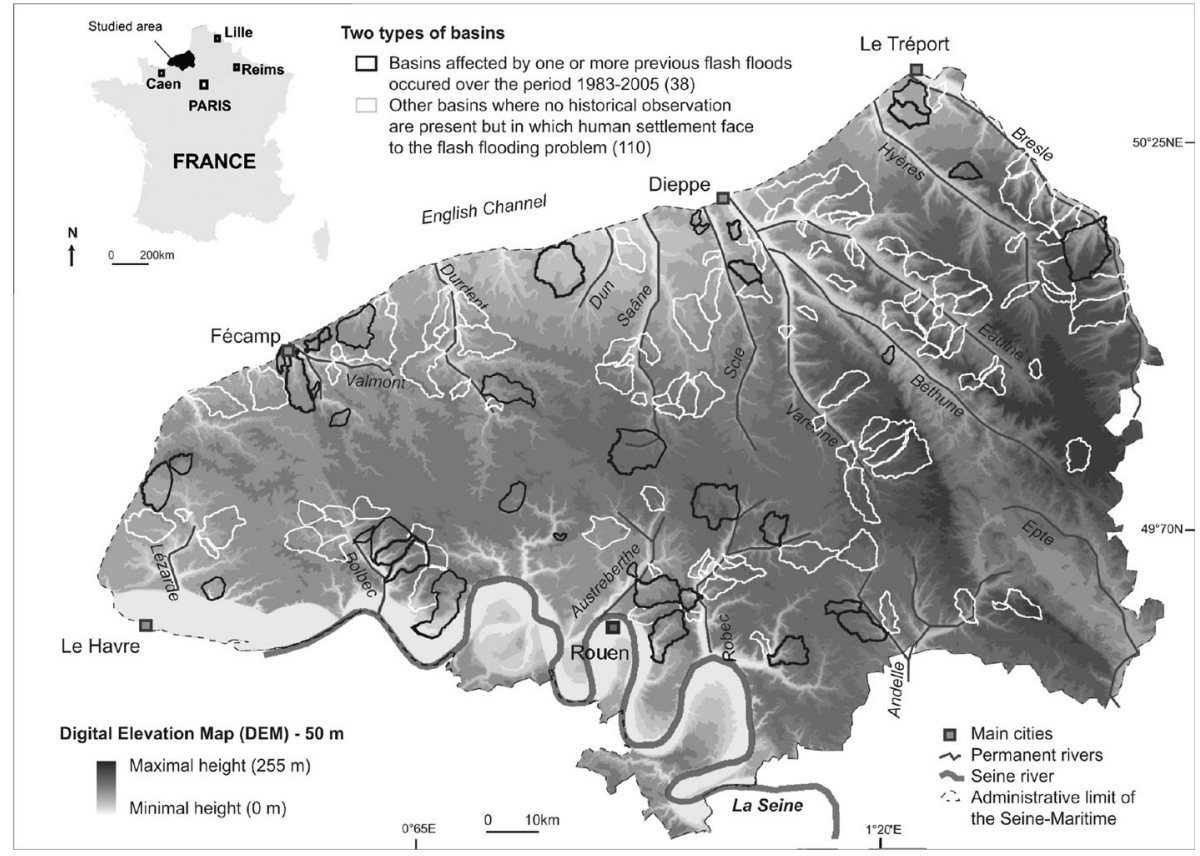

Fig. 1 Schematic topographic and hydrographic conditions in Seine-Maritime (northern France) and location of the 148 studied basins including the 38 basins affected by previous flash floods (1983-2005)

where processes between independent interacting entities behave according to the local environment (Teles et al. 1998). But the agent-based modelling applications remain less used than $\mathrm{CA}$ in geomorphology as the attention is more drawn on interactions between human or autonomous entities, more than on physic components, and because CA conveniently have an inherent spatial structure.

Another modelling approach is distributed modelling, improving the lumped models that only predict discharges at final outlets. However, even though distributed hydrological models, also based on the Digital Elevation Maps (Moussa and Bocquillon 1996; Cudennec et al. 2002; Kirkby et al. 2005), are supposed to be spatially explicit over the entire basin, they are usually validated and uniquely calibrated at the outlet. None of them allow for the estimation of potential surface flow concentration in all parts of a basin since the drainage limit divide (Douvinet et al. 2013). Previous studies are also focused on the relation between the global catchment morphology and its hydrological response measured at the final outlet. These studies underlined the difficulties encountered when linking local responses (sub-basins or hillslopes) to this global behaviour, and this aim has been one of the main issues for geomorphologists since the 1970s (Veltri et al. 1996; Rodriguez-Iturbe and Rinaldo 1997; Schmitz and Cullmann 2008). A few studies have successfully shown that the network organization plays a key role on hydrological functionality (Dietrich et al. 1993; Vogt et al. 2003). The CA RUICELL partially overcomes such difficulties and also implicitly captures the channel network structure and its influence on flood through scales. 


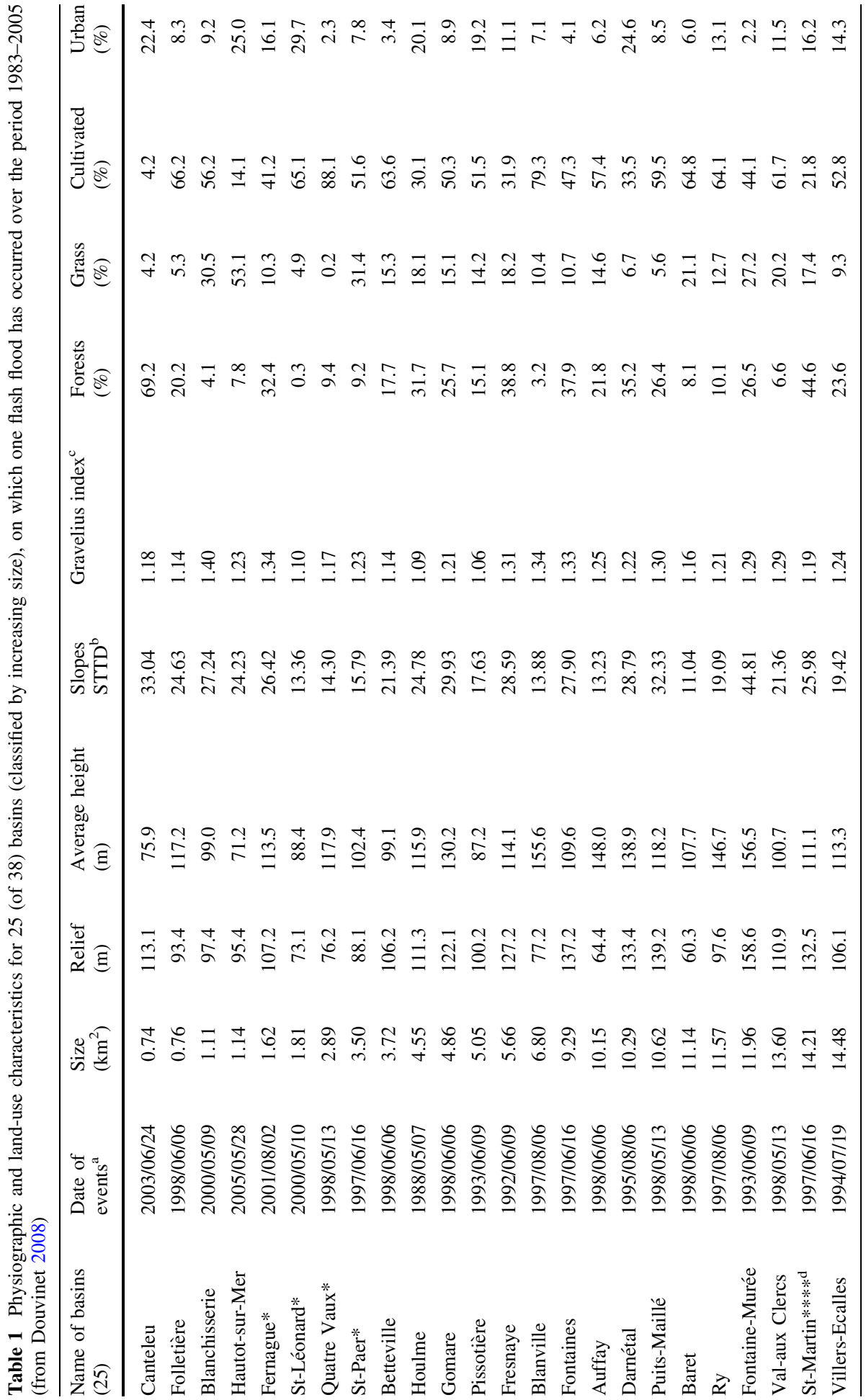




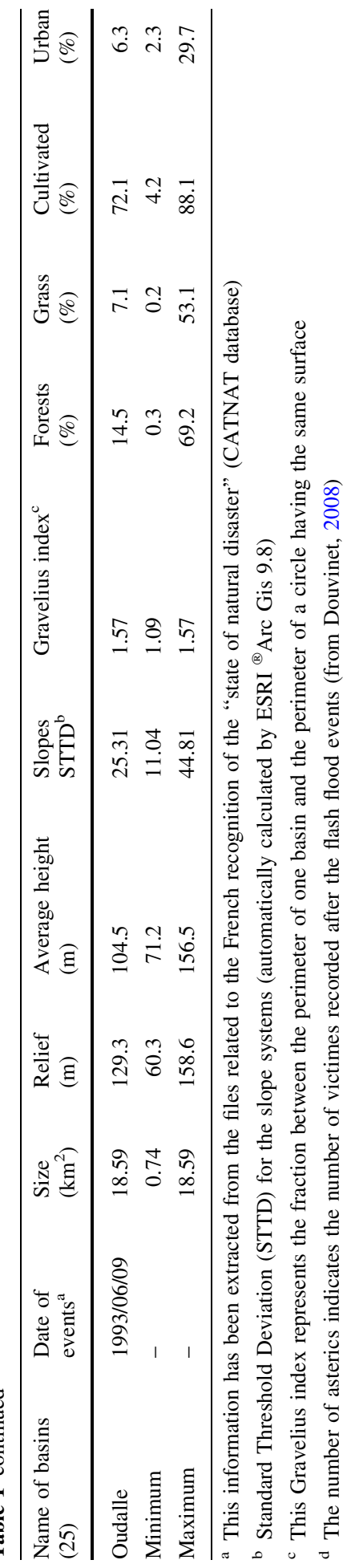




\subsection{The RUICELLS' spatial structure and conceptual design}

Similar to other hydrological or geomorphological CA models, the RUICELLS model establishes a link between topographic variables and hydraulic variables. In this subsection, we focus on RUICELLS' spatial structure and conceptual design, more than on all the mathematical relations underlying the process representation that is too cumbersome and too space consuming. A full description of the RUICELLS model, including its mathematical structure, can be found in Delahaye et al. (2001), Langlois and Delahaye (2002), Jaziri 2004 and Douvinet et al. (2013).

The diversity of the topography and the variety of the mechanisms involved precludes a global modelling of the run-off process (Mita et al. 2001; Palacios-Vélez et al. 1998; Tucker et al. 2001) and it requires a sharp division of the concerned area into homogeneous and interconnected cells. In RUICELLS, the original CA concept is generalized to incorporate the variety of the topographical conditions: elementary surfaces on hillslopes, linear portions of thalwegs, and local depressions. The spatial dimensions of cells thus are 0,1 , or 2 (point, line, or surface). Moreover, the connections of the automata are directed only by the neighbourhood topology of cells, but also by morphological links organizing the space: the links of discharge between the cells and the links of overflow between the sub-basins.

The spatial domain is discretized as a Triangular Irregular Network (TIN), based on the Digital Elevation Map (DEM) according to square grid (Fig. 2a). Two techniques are available to create a lattice: a function obtained by the calculation of differences between neighbouring cells (Laurent et al. 1998), or the meshing in finite elements which gives a continuous interpolation between points of the DEM. We have chosen the latter, which gives for each point its elevation and its vector normal to the surface (Fig. 2b), allowing the calculation of every measure of size related with the local shape of the terrain (slope angle, exposition, run-off vector, surfaces, volumes, and flows). Consequently, we have divided each square cell into two triangles, choosing one of the diagonals to define the triangle (Fig. 2c). This choice is relevant because the diagonals do not cross at the same height. To improve the outflow, the diagonal with the minimum height at the crossing point and with no risk of obstructing a stream channel have been chosen. The steepest downward link determines the flow direction, analogues to D1 and D8 algorithms for other square lattices (O'Callaghan and Mark 1984; Tarboton 1997). The TIN structure, due to its linear applications, offers the simplest finite elements model and a substantial gain if we operate on a PC with a very large amount of cells. Importantly, this spatial structure overcomes one of the main disadvantages of many CA models, namely that flow directions are constrained to $45^{\circ}$ intervals at any cell.

In order to access the geometric information, the topological graph applied on the TIN structure is composed of three main features: node, arc, or triangle (Fig. 2d), inducing the following relational tables. The arcs play a major role: each arc is connected to two nodes and two triangles, and a morphological attribute may be given to it by the relative heights of the former and the relative slope angles of the latter. Comparing the heights of two nodes, we can see if the connecting arc is downhill, uphill, or flat. As for the triangles, two of them (side by side) may be also, individually, downhill, uphill, or flat. An arc whose final node is lower than the initial one is downhill but if its two neighboring triangles are downhill towards it, it equals a downhill thalweg (Fig. 2d). The typology gives $3^{3}=27$ theoretical possibilities. After eliminating some rare and specific situations, we have kept several attributes for the arcs. The "external limit" has been introduced to handle with the limits of the studied area. The "flat" is attributed to the limit between two flat triangles. It must be stressed that these attributes are purely local: if an arc equals a downhill thalweg, 
(a)

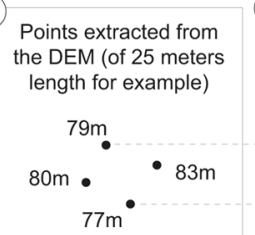

(b)

Two techniques for the spatial domain discretisation
(and advantages for triangular mesh)

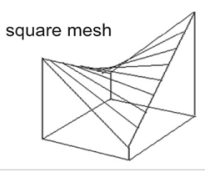

d)

Links between two cells presenting different slopes (in 2D and representation in the topological mesh)

crest
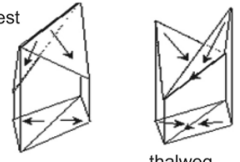

thalweg

f

A triangular and regular mesh for hydrological fluxes
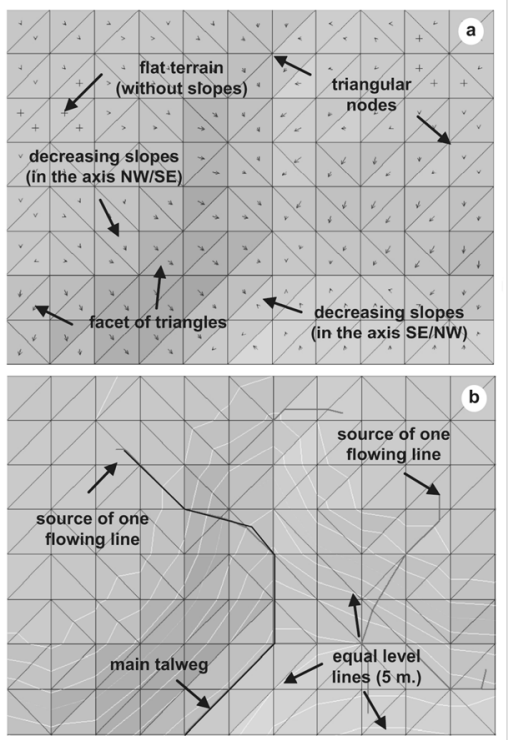

c

Creation of a topological mesh (triangular regular lattice)

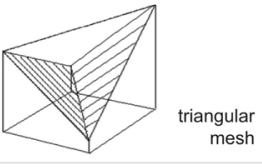

(e)

Three deterministic hydrological conditions associated to geometric information for each cell

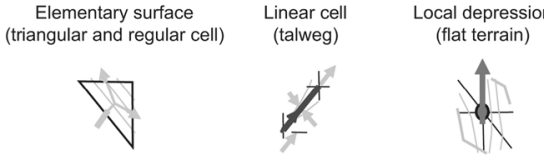

g)

Different flow speading according to slopes and water heightq

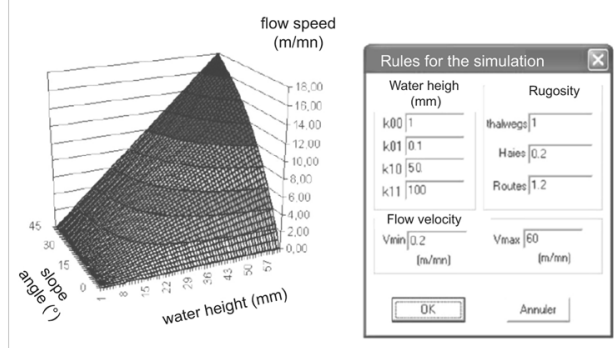

(h)

Conceptual design for the water surface flowing
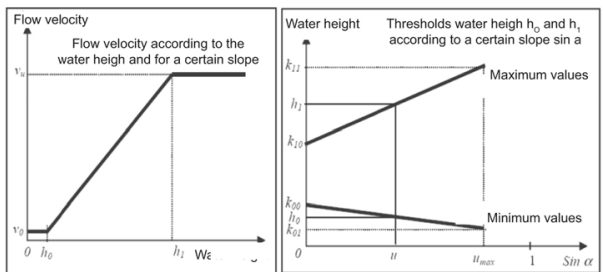

Fig. 2 Rules and main characteristics of RUICELLS (modified from Delahaye et al. 2001)

there is no continuity for the downstream arcs (Douvinet et al. 2009, 2013). Yet its knowledge is important to determine the run-off process, which is linear along this arc, while if the arc attribute is left slope, the run-off is a sheet flow and its direction transversal.

A large thalweg is formed by a certain amount of triangles, in which there is a sheet flow transversal to the arcs (Fig. 2fa). The local attributes of arcs are no longer sufficient to shape the network. Then, the links between the elements (poles, arcs, and triangles) of the topological graph must be taken into account. The resulting graph is more complex than one oriented dual topological graph because it connects together poles, arcs, and triangles. A water drop laid on a triangle can flow towards the neighbouring triangle (if the connected arc is a left slope, Fig. 2d) or in the arc itself if it is a downhill thalweg. This drop can also 
be stopped in a pole if it arrives in a closed depression (Fig. 2e). Additional complications may arise in certain conditions. For example, channel streams in dry valleys are mostly ephemeral, using the pre-existing drainage networks (Fig. $2 \mathrm{fb}$ ): the thalwegs may not have a continuous declivity but can consist of a sequence of little slopes creating a series of discontinuities in the flow. Another problem derives from the DTM: its $25 \mathrm{~m}$ horizontal resolution smoothes out several features (e.g. small gulleys) that occur in many of the basins and the vertical precision of one meter for the elevation data produces, in approximately flat areas, a large number of horizontal triangles in which the calculation of the vector of greater slope angle is not easy to calculate. When the water flows on grass or on cultivated area, the common mathematic models (such as Saint-Venant 1D or 2D) are also not useful because laminar flow does not really exist. Thus, the effects of gravity are computed with energy-based calculations, and velocity of flows does not directly depend on its mass:

$$
\Gamma=k g \sin \alpha
$$

with $g$ the gravity influence $(9.81 \mathrm{~m} / \mathrm{s}), k$ a constant factor, and $\alpha$ the slope angle. The flow proportionally increases according to the time and the thickness quickly stabilizes flow speed in flat areas. The Saint-Venant equations indicate that flow speed $(v)$ proportionally increases with water height, computing constant flowing $(h, y)$ as a function of slope percent $(\theta)$ and discharge $(Q)$. This idea can be obtained by the following formula:

$$
\begin{gathered}
v=\sqrt[3]{\frac{8 g Q \theta}{f}} \\
h=\sqrt[3]{\frac{f Q^{2}}{8 g \theta}}
\end{gathered}
$$

with $v$ the flow speed and $h$ the water height $(\mathrm{m})$. Therefore, the formula appears obvious since it derives from a model that calculates, at the same moment, the water height and it speeds according to a specific discharge. But in small and dry valleys, the discharges are not known in advance. Furthermore, the water height is weak (a few millimeters), slope gentle (a few degrees) and the friction force high face to water quantity. Then, we develop a linear model in which rules can be easily formalized. We define the $v$ function (flow speed) with two variables (Fig. $2 \mathrm{~g}$ ), in which $h$ equals to the water height and $u=\sin \alpha$ the slope angle.

Six flow parameters are defined in RUICELLS (Fig. 2h): the water height required to maintain a constant flow when the slope angle is negligible $\left(k_{00}=1\right)$; the water height needed for a constant flow if slopes are higher $\left(k_{01}=0.1\right)$; the water height threshold up to which flow speed attempts $v_{0}\left(k_{10}=50\right)$ or $v_{1}\left(k_{11}=100\right)$; the maximum speed if slope angles are negligible $\left(v_{0}=0.2\right)$ or higher $\left(v_{1}=60\right)$. All these parameters have been calibrated on the basin of Saint-Martin-de-Boscherville $\left(13.4 \mathrm{~km}^{2}\right)$, partly by comparing with simulations results of the STREAM model (Merle et al. 2001) and partly by comparing with flow estimations derived from the maximum slack water deposits observed after the June 16th, 1997 flash flood event (Delahaye et al. 2001).

\subsection{Data acquisition and chosen parameters}

To simulate potential hydrological responses to various rainfall intensities, three types of input data are needed, aside from the DEM (source: IGN; resolution of 25 meters in this 
study): (1) a relevant land-use map (LUM); (2) water infiltration capacities; (3) the definition of rainfall intensities (with real data or not).

Two types of GIS data were used to produce the LUM. The Corine Land Cover (CLC) permits to delineate real-world objects (lakes, cultivated fields, meadows, forests, industrial areas, and natural areas). The CLC (with 46 hierarchical levels of classification) has been produced by the Agency of Development at the European scale and is derived from satellite images. By itself, these data are insufficient as it does not accurately delineate very small areas $\left(<0.05 \mathrm{~km}^{2}\right)$ and its precision is not enough to detect run-off sources. Therefore, we improved CLC (2006) using the Geographical Parcel-Based File (GPBF) (2010), created to help farmers apply for European Common Agriculture funding and kindly provided by the DREAL-Normandy service. These data (with 114 categories) enable us to precisely detail the dominant yearly type of land use (wheat, corn, flax, potatoes, or others) for each season (spring and winter periods) over the last 4 years (2007-2010). GIS ground-truthing erased errors due to geometric intersections between CLC and GPBF. The new cross-combined data give satisfying results as shown in the overview for the basin of Mesnil-Val (Fig. 3). This basin $\left(9.88 \mathrm{~km}^{2}\right)$ has an elevation ranging from 26 to $210 \mathrm{~m}$ over a distance of $1.1 \mathrm{~km}$. Cretaceous calcareous rocks dominates its geology. Grasslands exist over the slopes exceeding $5 \%$ in the middle parts of the basin and interact with springer peat, maize, sugar beet, or wheat in downstream and upstream parts. A flash flood occurred on May 10th, 2000, and inundated the outlet (namely Mesnil-Val) and the village of Rainville (Fig. 3). Although the LUM was mapped after the event (2000), it presents few differences with the situation in 2000, i.e. the flood susceptibility remains high because land use does not change significantly in 10 years $(+3.2 \%$ for cultivated areas, $-1.8 \%$ for grasslands). The performance of CLC-GPBF is relevant for several reasons. Other data (earth observations or multi-spectral images) capture land cover at a given moment without allowing the assessment of the seasonality and of the evolution of agricultural practices, while surface states play a key role on run-off productions (Cerdan et al. 2002). GPBF is available over the entire Seine-Maritime and permits a transferable method over the studied basins. The flash flood susceptibility conducted in this study is based on the most detailed and on the most recent data (2010), because simulations were launched in 2011. Nonetheless, we shall update the LUM and compare the 2010 susceptibility assessment with those obtained for 2014 for example. Indeed, the ability to easily update the LUM and the implementation of GIS data within the RUICELLS model are two major advantages of our study design.

To associate water infiltration capacities with the LUM, we use the latter rather than run-off coefficients, for three reasons: (1) the infiltration capacities account for soil roughness, its sedimentology and the vegetation cover at one given moment (Cerdan et al. 2002); (2) run-off due to infiltration saturation, as per Horton's theory (1933), prevails during flash flood events (Kirkby et al. 2005); (3) the run-off coefficients give a minor role to cultivated areas and tend to underestimate run-off cumulative amounts (Douvinet 2008). Previous research (Benkhadra 1997; De Roo 1999; Lecomte 1999; Joannon 2004; Souchère et al. 2005) has been conducted over the entire Seine-Maritime to define infiltration capacities at larger scale. We use smallest infiltration capacities (Table 2) to consider the worst-case scenario, where antecedent rains have saturated the soils and, consequently, water surface flows should occur in a few minutes. Even though these assumptions may not reflect the reality for a given storm event, the simulated flash flood susceptibility will alert forecasters and planners as soon as possible. The implemented coefficients are simplified for the main land-use type, and several data have been adjusted according to field experiments conducted after previous severe flash floods (Delahaye et al. 2001). Sensitive 
Land Use Map (LUM) computed for the Mesnil-Val Basin $\left(9.88 \mathrm{~km}^{2}\right)$

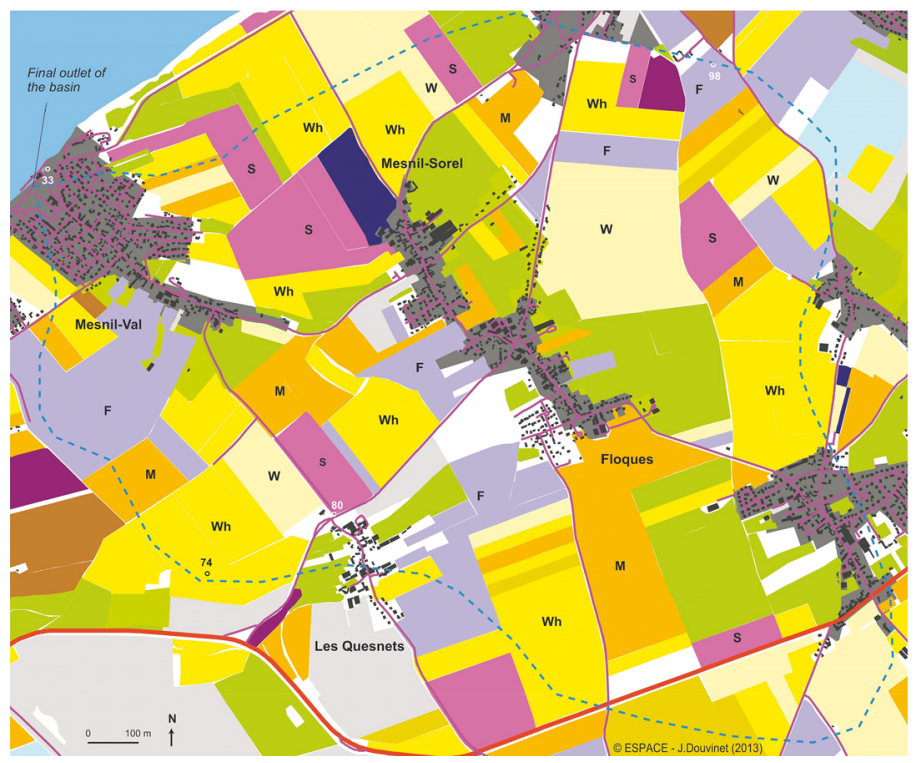

Objects delinated by the Corine Land Cover data (2006)

Dense urbanized areas Commercial//ndustrial areas Stones and littoral area Athletic equipments Permanent grasslan Leaved forests Confier forests Scrub/Moor Marsh/Swamp Water (stream/lak

Dominant yearly land use issue from the Geographical ParcelBased file (2010)

w Wild-out (winter/spring)

$s$ Sugar beet

Hard or tender wheat (winter/spring) Rapeseed (winter/spring) Horse bean (commercial or not) Filing/gel (fixed/annual) Industrial gel (fixed/annual) F Flax (bulk/untextile) Maïze (tender/silage) Market gardening/Moor Barley (winter/spring) Potatoes (commercial or not) Springer pea Grassland (permanentitemporan) Other cultivated areas Non affected (less than 10 parcels)

Other informations

.: Houses (BD-TOPO IGN 2008) 124 Elevation point $(\mathrm{m})$ Main roads (highway/national road) Other roads (until by-road) Drainage divide limite Danche (Sea)
Manche

Fig. 3 Example Land-Use Map (LUM), combining Corine Land Cover (CLC 2006) and Geographical Parcel-Based File (GPBF 2010), over the basin of Mesnil-Val $\left(9.88 \mathrm{~km}^{2}\right)$

cultivated areas in terms of run-off production play an important role: silage corn and sugar beet $\left(3 \mathrm{~mm} \mathrm{~h}^{-1}\right)$ have smaller infiltration capacities than potatoes $\left(4 \mathrm{~mm} \mathrm{~h}^{-1}\right)$ or winter wheat or rapeseed $\left(5 \mathrm{~mm} \mathrm{~h}^{-1}\right)$, whereas forest areas and permanent grasslands have higher capacities $\left(50 \mathrm{~mm} \mathrm{~h}^{-1}\right)$. Initial rains have also been cut off $\left(5 \mathrm{~mm} \mathrm{~h}^{-1}\right)$ to account of soil porosity and vegetation imbibition. These assumptions can be criticized, because intensities at fine time step (5 min) strongly affect these factors (Cerdan et al. 2002), whereas infiltration capacities used in this study never evolve during the modelling process. This point frequently poses a problem in numerous modelling approaches (Nearing et al. 2005). Nonetheless, the assumptions are retained here for simplicity and tractability.

To account for rainfall variability, we assess the susceptibility of basins playing with different rainfall intensities. Two choices were possible: either we implement rains according to the frequency analysis methods for extremes, i.e. the SHYREG database (Renard et al. 2013), or we consider project rainfall scenarios for all basins. The first choice was not appropriate for this study for two reasons: (1) the statistic calculation of rains presenting small probability and large return periods introduce high uncertainties; (2) earlier research (Douvinet et al. 2009) underlined differences between measurements by official stations, radar, and volunteer stations. For the storm event of July 25th, 2000, for example, Neuville-sur-Dieppe has officially measured $33.2 \mathrm{~mm}$ in $24 \mathrm{~h}$, whereas the radar pixelated 50-75 $\mathrm{mm}$ in $2 \mathrm{~h}$ (at a distance of $2 \mathrm{~km}$ from the station) and a volunteer cumulated $78 \mathrm{~mm}$ in $1 \mathrm{~h} 15 \mathrm{~min}$. Thus, even if rains are not representative of the extreme possible events on each basin, we created a set of potential rainfall scenarios of different intensity and duration: 20, 30, 40, and $50 \mathrm{~mm}$ in $1 \mathrm{~h} ; 30,40,50$, and $60 \mathrm{~mm}$ in 2, 3, and $6 \mathrm{~h}$, Even though this flood susceptibility is likely overestimated in these worst-case scenarios, the highest intensities $(50 \mathrm{~mm}$ in $1 \mathrm{~h}$ ) could locally happen. 


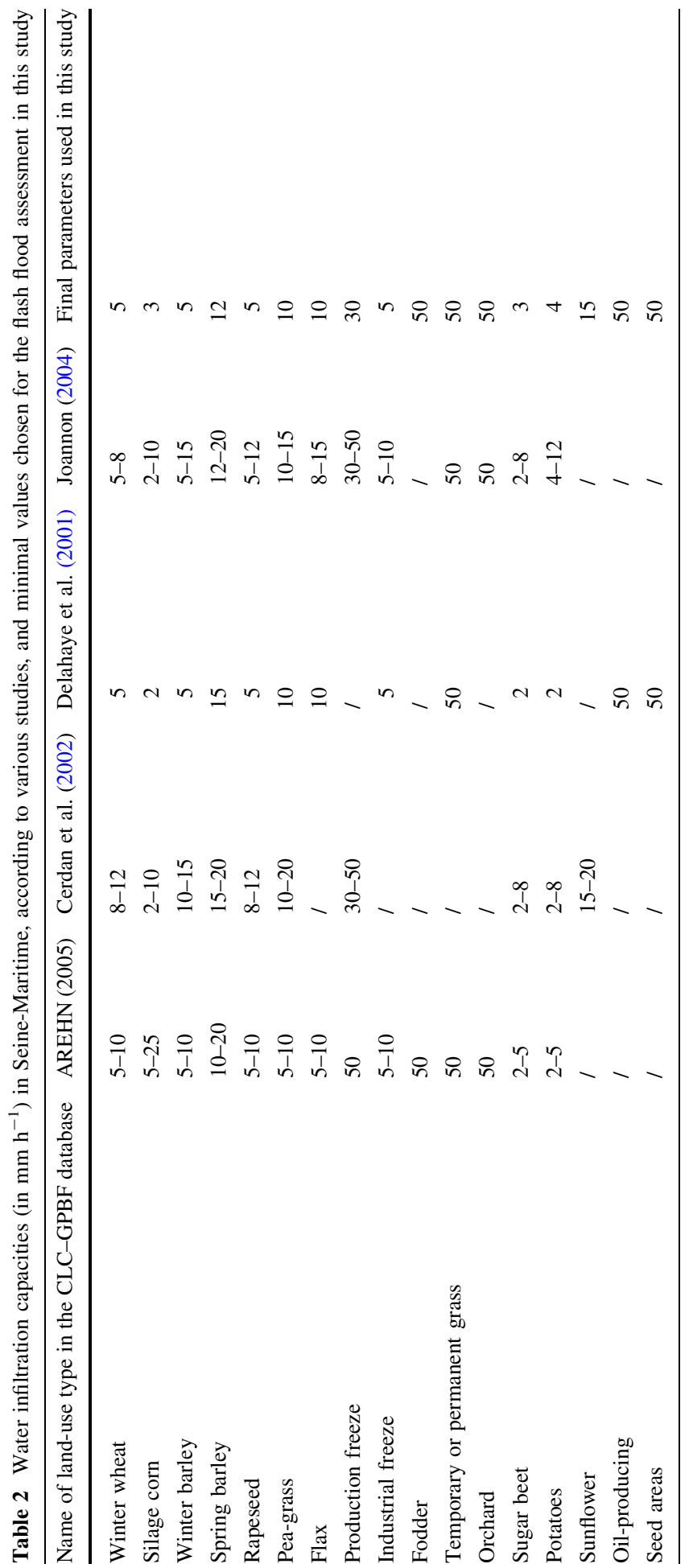




\subsection{Simulation set-up and outputs}

Data are implemented as follows: (1) download the Digital Elevation Model in the RUICELLS model, which automatically converts it in a triangular and regular lattice (.mnt) and attributes hydrological roles to triangles, links, and nodes; (2) the user identifies one or several outlet(s) - the basin limit is automatically calculated; (3) attributes of the Land-Use Map (LUM), which is converted in a generate format in GIS (.gen), are exported and transferred on lattice, whereby a parcel covering up to $50 \%$ of one cell $(25 \mathrm{~m} \times 25 \mathrm{~m})$ automatically defines it (similar geographical coordinates and GIS projection are required to avoid cartographic disturbances); (4) water infiltration capacities are linked to the LUM (.txt); (5) the user defines rainfall data (.txt). Following these steps, the simulations can be launched. At the end of the modelling process, the model outputs a graph that shows the evolution of discharges through time according to the rainfall input, and a map indicating the run-off amounts on each cell. An example is shown on the basin of Mesnil-Val (Fig. 4). These simulations not only allow estimation of probable hydrological responses for a specific rain, but also the identification of spatial interactions between run-off production areas and points of measurement (Delahaye et al. 2001), at plot to basin scales, as well as a further understanding of important discharges and run-off amounts when rains exceed a critical intensity. For example, some basins may not respond gentle rainfall intensities, but produce high discharges after critical rainfall.

\subsection{Limits for the modelling performance assessment}

Normally, after a model is developed, it is tested before being put to use as a predictive or explanatory tool. This is a form of quality assurance, and it involves the simulation of a situation for which observed data are available (Van de Wiel et al. 2011). For this instance, the model parameters have been only calibrated for the 1997, June 16th event (Delahaye et al. 2001), through the simulation of the diffusion of the run-off process in two basins. In these two cases, the major simulated areas sensitive to the run-off processes equal to the real production areas and the divergence with the observations is only important in the upstream southern part of a basin. The simulation, indeed, locates a major flow, which has not been observed in this area; this is due to the fact that the simulation has not taken into account the influence of the highway crossing the upstream part of the basin. This highway stopped the flow and produced a flood leveling, generating retentions of water along many embankments. The observation shows the limits of the model, but stresses also the efficiency of such a tool to evaluate the incidence of an implement on the hydrological behaviour of a basin. On the other hand, these results show the accuracy of this approach and how, starting from a simple data set, it is possible to set-up a cartographic presentation of the run-off dynamics. Simulations also give a good agreement in comparison with estimations proposed by more complex hydrological models (GR4J, STREAM, and LISEM) and those derived from water deposits (Merle et al. 2001). Our simulations cannot be verified quantitatively due to a lack of independent data. Validation occurs only on a scenario basis, and it is always possible to attribute errors of the simulations to inaccuracy of the initial or external forcing conditions, rather than to inaccuracy of the model's hypotheses (Van de Wiel et al. 2011). Even though Begueria (2006) use, for example, confusion matrices to compare modelling and recorded events in true or false positives or negatives information (Kappes et al. 2011), the low availability of hydrological data of events renders such approach impractical. Lacking an independent quantitative validation, 


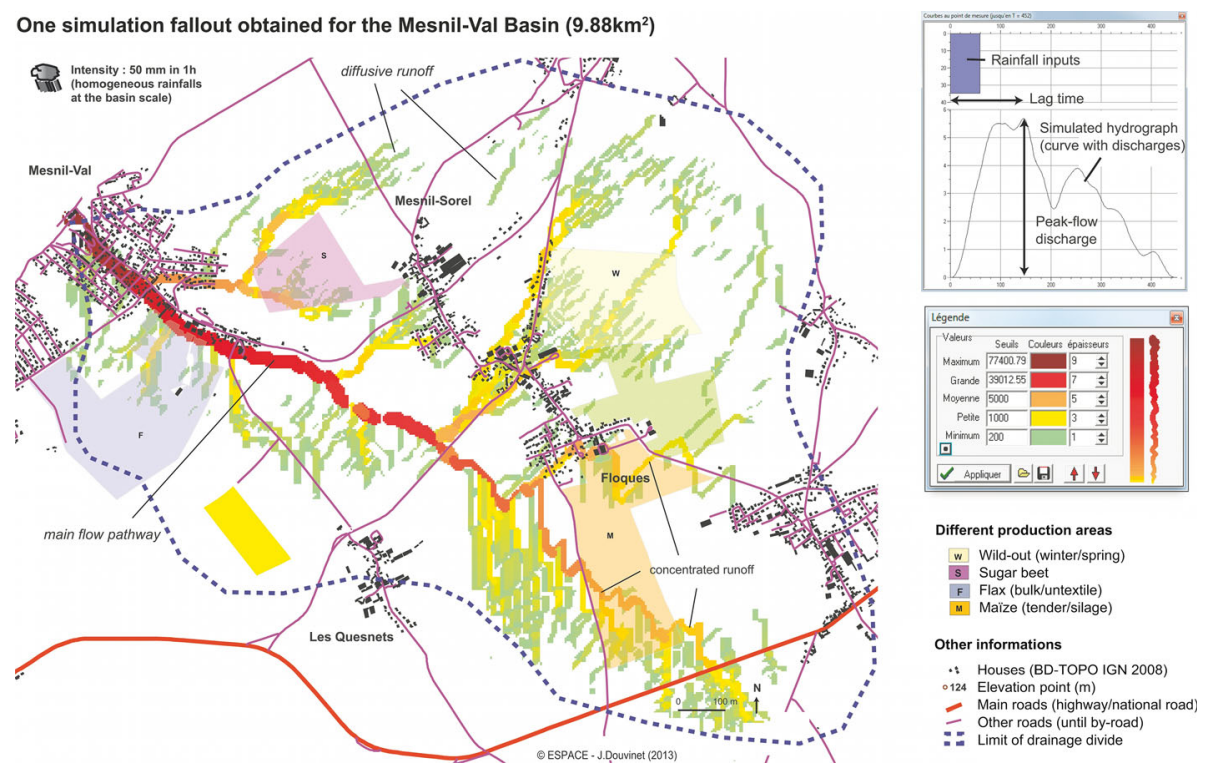

Fig. 4 One simulation fallout obtained on the basin of Mesnil-Val $\left(9.88 \mathrm{~km}^{2}\right)$, permitting to simulate and to map the potential hydrological response for a storm event of $50 \mathrm{~mm}$ in $1 \mathrm{~h}$

these first modelling results are only evaluated in a qualitative way, which necessitates a careful interpretation (see Sect. 5.1).

\section{Results and susceptibility assessment}

Simulations are analyzed for three main variables that characterize basin susceptibility of flash flooding: peak flow discharge $(\mathrm{Q})$, peak unit discharge $\left(\mathrm{Q}_{\mathrm{s}}\right)$, calculated by dividing $\mathrm{Q}$ by the basin size and lag time (T), i.e. the duration between the beginning of rainfall and the onset of peak discharge (and not the time between the onset of peak rainfall and the onset of peak discharge, due to the simulation configuration), for each of the 148 studied basins and each of the 16 rainfall intensities. Even though results are available on each basin, they are presented here in aggregated form, i.e. at large scale, to facilitate the susceptibility analysis.

\subsection{Peak flow discharges}

The model allows identifying that the number of susceptible basins strongly increases with rainfall intensity. In the following analysis, we use three arbitrarily chosen peak discharge thresholds to identify small (from 4 to $7 \mathrm{~m}^{3} / \mathrm{s}$ ), medium (from 7 to $10 \mathrm{~m}^{3} / \mathrm{s}$ ), and high $\left(>10 \mathrm{~m}^{3} / \mathrm{s}\right)$ susceptibilities to flash flooding. For events with $30 \mathrm{~mm}$ of rainfall in $1 \mathrm{~h}, 13$ basins have peak flows with $Q>4 \mathrm{~m}^{3} / \mathrm{s}$ (Fig. 5a), but only one exceeds $7 \mathrm{~m}^{3} / \mathrm{s}$ (Val-deSaâne). At $40 \mathrm{~mm}$ in $1 \mathrm{~h}, 70$ basins have $Q>4 \mathrm{~m}^{3} / \mathrm{s}$ (Fig. $5 \mathrm{~b}$ ), 17 of which have $Q>7 \mathrm{~m}^{3} / \mathrm{s}$, and 3 have $Q>10 \mathrm{~m}^{3} / \mathrm{s}$ (Val-de-Saâne, Lézarde amont and Val-aux-Scènes). 
At $50 \mathrm{~mm}$ in $1 \mathrm{~h}, 72 \%$ of the studied basins (104 out of 148 basins) have a $Q>4 \mathrm{~m}^{3} / \mathrm{s}, 56$ of which have $Q>7 \mathrm{~m}^{3} / \mathrm{s}$, and 21 have $Q>10 \mathrm{~m}^{3} / \mathrm{s}$ (Fig. $5 \mathrm{c}$ ).

Similarly, the susceptibility decreases for rainfalls more spread over time. For example, for storm with $50 \mathrm{~mm}$ in $2 \mathrm{~h}$, only 33 basins have $Q>4 \mathrm{~m}^{3} / \mathrm{s}$ (Fig. $5 \mathrm{~d}$ ) and 6 basins have values up to $7 \mathrm{~m}^{3} / \mathrm{s}$. In terms of land use, susceptibility to flash flooding is higher in basins where percentages of sugar beet, corn, maize, and flax are important. These basins are subject to flash flooding at $30 \mathrm{~mm}$ in $1 \mathrm{~h}$, and even react to lower intensity storm events of longer duration (e.g. $40 \mathrm{~mm}$ in $2 \mathrm{~h}$ or $50 \mathrm{~mm}$ in $3 \mathrm{~h}$ ). Conversely, the peaks of discharges of other basins, in which cultivated areas are more dispersed, suddenly increase $\left(>7 \mathrm{~m}^{3} / \mathrm{s}\right)$ for more intense storm event of $50 \mathrm{~mm}$ in $1 \mathrm{~h}$. Grasslands are sufficient to reduce the runoff production coming from upstream parts for gentle rainfall intensities $\left(<40 \mathrm{~mm} . \mathrm{h}^{-1}\right)$, but become inefficient for more intense rains. Basins with other dominant land use present intermediary behaviours between these extremes.

At larger scales, several basins with high responses are spatially concentrated, especially along the coastal areas along The Channel, the Seine River, or along a few tributaries (Scie, Durdent or Saâne rivers). In this case, several floods can arrive at the same moment and generate high-risk levels in case of an extended thunderstorm $\left(>10 \mathrm{~km}^{2}\right)$. Flash floods from similar events, but occurring over more isolated basins (such as in the eastern part of the department), are easier to manage and to prevent. In a qualitative way, the comparison with historic flash floods occurrences (over the period 1983-2005) shows a good correlation with the highest $Q$ values: the three basins identified as the most susceptible in our simulations for storm events of $40 \mathrm{~mm}$ in $1 \mathrm{~h}$, also have historically observed flood events). However, the validations are not systematic. For example, flood events have been observed in 12 of the 21 basins identified, as the most sensitive for $50 \mathrm{~mm}$ in $1 \mathrm{~h}$, while the results for $30 \mathrm{~mm}$ in $1 \mathrm{~h}$, as well as for $50 \mathrm{~mm}$ in $2 \mathrm{~h}$, are a less successful indicator. Therefore, the $Q$ values need to be divided by the basin size, since weak peak flow discharges do not have the same hydrological significance in small and large basins.

\subsection{Peak unit discharges}

Previous studies carried out on Mediterranean floods (Gaume et al. 2009) highlighted that surface flows become strongly erosive when peak unit discharges $\left(Q_{s}\right)$ exceed at least $0.7 \mathrm{~m}^{3} / \mathrm{s} / \mathrm{km}^{2}$. An earlier study (Douvinet and Delahaye 2010), carried out a few days after several flash floods on five areas in northern France, permitted to estimate a threshold of $1 \mathrm{~m}^{3} / \mathrm{s} / \mathrm{km}^{2}$ for minor erosion forms and of $1.5 \mathrm{~m}^{3} / \mathrm{s} / \mathrm{km}^{2}$ for major incisions on soils (gullies) or roads (destruction of network infrastructure). Thus, the analysis of simulated $Q_{s}$ takes into account these thresholds. Occurrence of peak unit discharges strongly increases with rainfall intensity. For storm events with $30 \mathrm{~mm}$ in $1 \mathrm{~h}$, only 7 basins have $Q_{s}>1 \mathrm{~m}^{3}$ / $\mathrm{s} / \mathrm{km}^{2}$; at $40 \mathrm{~mm}$ in $1 \mathrm{~h}, 26$ basins present $Q_{s}$ exceeding this threshold (Fig. 6a), whereas 64 basins do so at $50 \mathrm{~mm}$ in $1 \mathrm{~h}$ (Fig. 6b).

Clear trends are observable, with, especially high $Q_{s}$ values at the outlets of dry valleys recorded to bigger rivers (Durdent, Valmont and Bolbec) and with the highest peak unit discharges occurring in the smallest basins. The basin size increases more quickly than $Q$ and this explains why high $Q_{s}$ values are rarely observable on "larger" basins (ranging from 10 to $20 \mathrm{~km}^{2}$ ). Even with the provision that these first modelling results need to be treated with care, three points are important: (1) small basins can produce high $Q_{s}$ values, independently of their land use, and rainfall-discharge models are insufficient to manage their susceptibility; (2) basins combining large basin area $\left(>10 \mathrm{~km}^{2}\right)$ and a $Q_{s}$ value greater than $1 \mathrm{~m}^{3} / \mathrm{s} / \mathrm{km}^{2}$ are the most sensitive since they can produce the most damaging floods; 

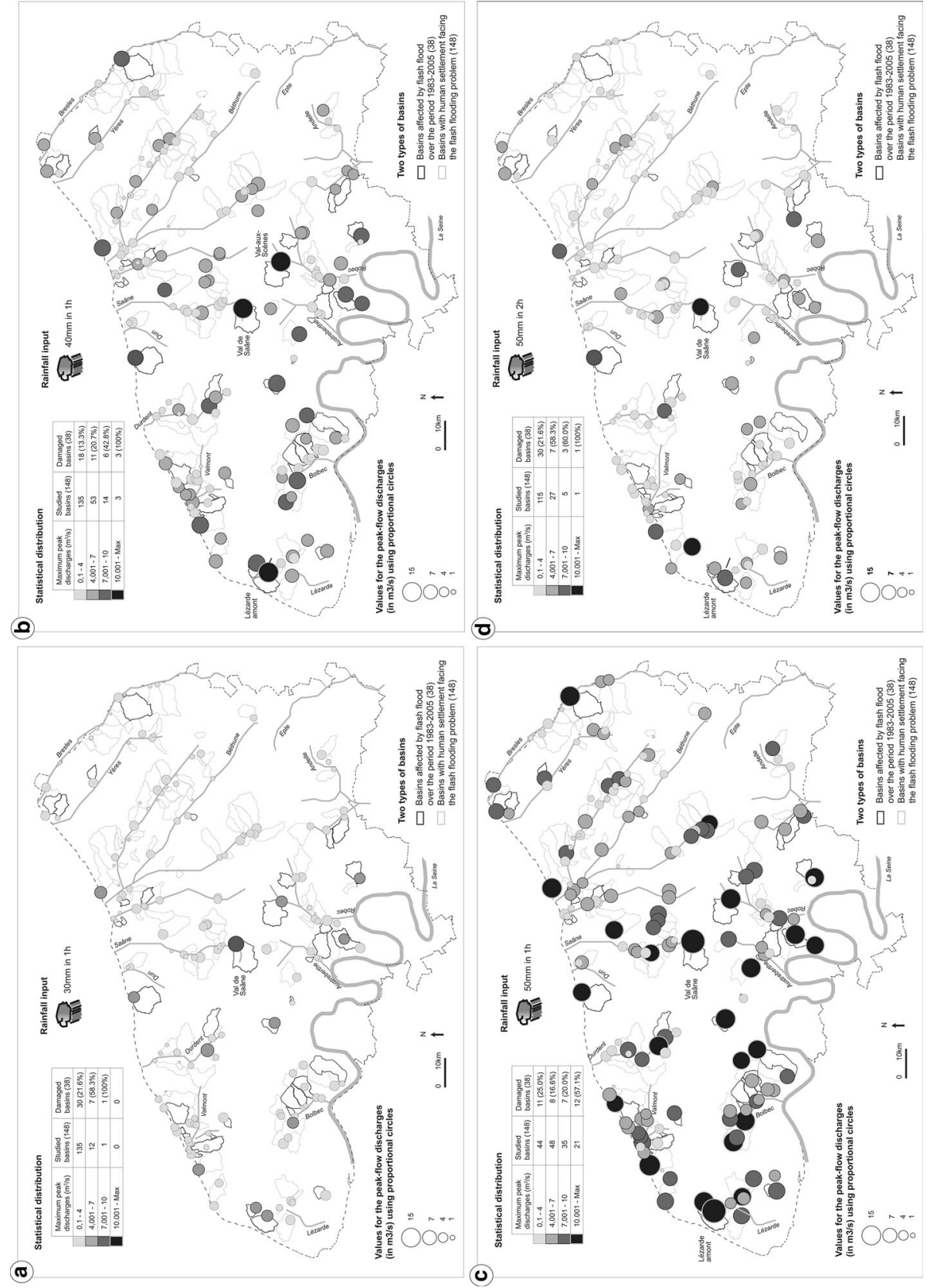

Fig. 5 Evolution of the peak flow discharges simulated by RUICELLS over the 148 studied basins, according to different intensities varying from $30 \mathrm{~mm}(\mathbf{a}), 40 \mathrm{~mm}(\mathbf{b})$ and $50 \mathrm{~mm}(\mathbf{c})$ in $1 \mathrm{~h}$ to $50 \mathrm{~mm}$ in $2 \mathrm{~h}$ (d)

(3) concentrated high $Q_{s}$ values induce high risk in several valleys (Lézarde, Valmont). In a qualitative way, the comparison with historic flash floods occurrences (over the period 1983-2005) shows a good relation with the highest $Q_{s}$ values (5 of the 9 basins identified 

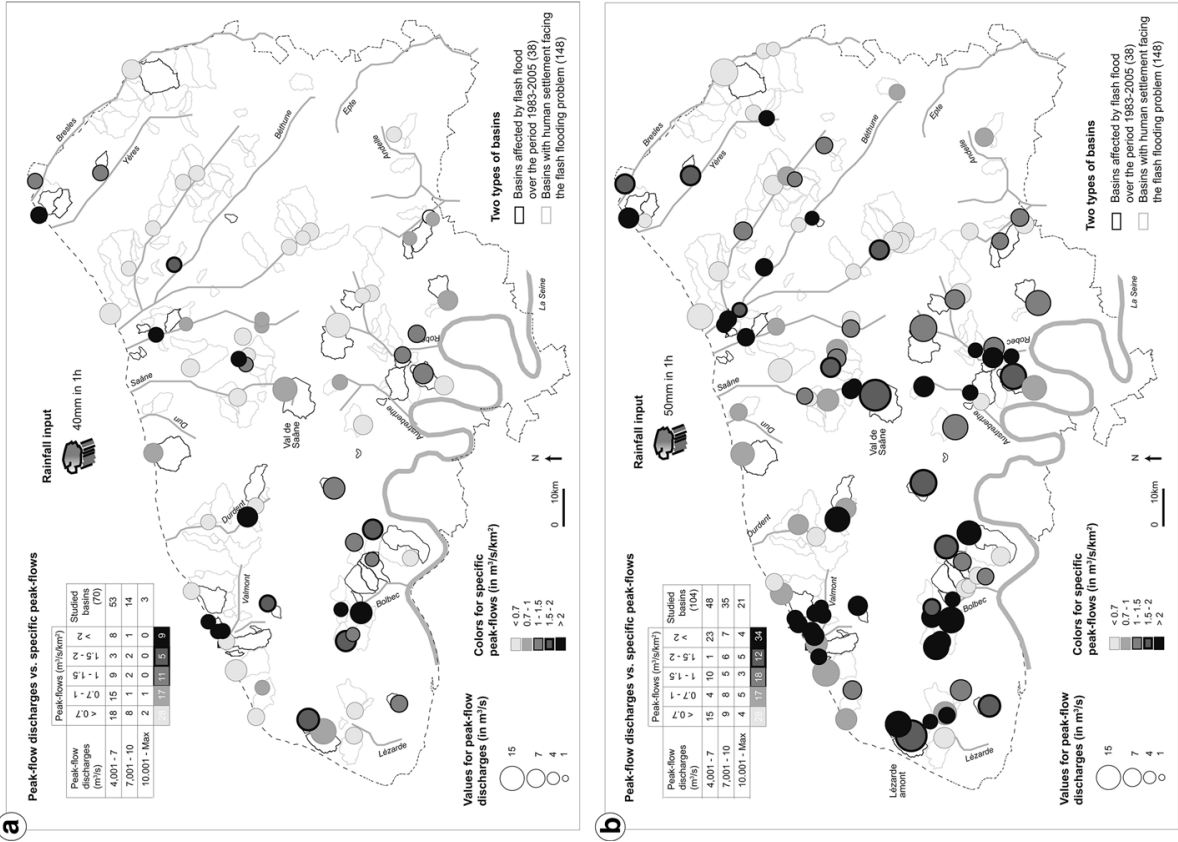

Fig. 6 Evolution of the peak unit discharges simulated by RUICELLS over the most sensitive basins (with peak discharges $>4 \mathrm{~m}^{3} / \mathrm{s}$ ) for storm events of $40 \mathrm{~mm}$ (a) and $50 \mathrm{~mm}$ (b) in $1 \mathrm{~h}$

as the most sensitive in our simulations for storm events of $40 \mathrm{~mm}$ in $1 \mathrm{~h}$, and 17 of the 34 basins for $50 \mathrm{~mm}$ of rainfall in $1 \mathrm{~h}$, had historic events).

\subsection{Lag times}

Another important question facing flood forecasters concerns the time they can have to alert the local authorities and the population for evacuation or for protection in areas at risk. The French Ministry of Environment and the General Delegation on Majors Risks (DGPR 2011) focus on this point after dramatic flash floods occurred in the western coastal part of France (49 deaths in February 2010) as well as in the southern part (25 fatalities in June 2010). To address this question, lag time, i.e. the time separating the beginning of rains and the occurrence of peak-flow discharge, was computed. Hydrologically, this differs from the time of concentration but it equals the duration of increasing flow (i.e. the rising limb of an hydrograph). The modelling results underline an increasing number of basins with short lag times as rainfall intensity increases. Eleven basins responding $40 \mathrm{~mm}$ in $1 \mathrm{~h}$ (Fig. 7a) present short lag times (i.e. in less than $2 \mathrm{~h}$ ) and only one of these (the Hanouard basin) has high $Q$, high $Q_{s}$, and short $T$. In contrast, 42 basins showing susceptibility for events with $50 \mathrm{~mm}$ of rainfall in $1 \mathrm{~h}$, and cumulating discharges up to $4 \mathrm{~m}^{3} / \mathrm{s}$ (Fig. 7b), have lag times less than $3 \mathrm{~h}, 22$ of which have lag times $<2 \mathrm{~h}$.

Several basins with peak flows ranging from 4 to $7 \mathrm{~m}^{3} / \mathrm{s}$ present the smallest lag times. The forecasters need to pay attention a greater attention on these as they can simultaneously produce several flash floods. Fortunately, all these identified basins very unlikely 
generate high flows at the same moment, since a storm event with $50 \mathrm{~mm}$ of rainfall in $1 \mathrm{~h}$ is very unlikely to occur over the entire Seine-Maritime. However, such storms can threaten this area in the future (following the predictive scenario 2.a; GIEC 2009) and can affect multiple basins locally if they are within close proximity. On the other basins, lag time increases with basin size, and forecasters should have more time ( $>3 \mathrm{~h})$ for alert. In a qualitative way, the comparison with historic flash floods occurrences (over the period 1983-2005) shows bad correlations (whatever the rainfall intensities) because only a few number of basins with historical floods present small lag times. Hence, this parameter is of paramount importance for forecasters, but seems to be the less useful to explain the flash flooding susceptibility (Fig. 7).

\section{Discussion}

The model's success in identifying flash flooding over a majority of basins where historical flooding indeed was observed indicates that it can be used to anticipate the flash floods in the Seine-Maritime department. However, since the simulations cannot be completely validated, care must be taken in interpreting the results.

\subsection{Validation efforts and limits}

The modelling validation is a fundamental step because this determines both the quality of the approach and the credibility of simulation results. In this study, the validation remains difficult due to the relatively low number of basins (38) affected by previous flash flood events (over the period 1983-2005). If we focus on the simulations obtained on these 38 basins, 17 (46\%) have peak unit discharges up to $0.7 \mathrm{~m}^{3} \mathrm{~s}^{-1} \mathrm{~km}^{-2}$ and 24 $(63 \%)$ have a peak flow discharge up to $4 \mathrm{~m}^{3} \mathrm{~s}^{-1}$, for a rain of $50 \mathrm{~mm}$ in $1 \mathrm{~h}$. Even if these results indicate that the model is successful in identifying flash flooding in most of these basins, this also indicates that a number of basins where historical flooding was observed did not experience flooding in simulations (14 out of 38, or $37 \%$ ). The identification of such differences can be explained by three arguments: (1) the real rains were more intense than our maximum intensity rainfall scenario (50 $\mathrm{mm}$ in $1 \mathrm{~h}$ ) - by running simulations with higher intensities (i.e. from 60 to $100 \mathrm{~mm}$ in $1 \mathrm{~h}$ ), we observe that all the 38 basins present high sensitivities for a rain up to $78 \mathrm{~mm}$ in $1 \mathrm{~h}$; (2) a higher sensitivity to run-off and flash floods (even though the peak unit discharge does not exceed $0.7 \mathrm{~m}^{3} \mathrm{~s}^{-1} \mathrm{~km}^{-2}$ ) because of a strong human settlement in the outlets-this hypothesis is attested on 9 basins out of the 14 studied; (3) the simulations underestimate the impact of the "built" environment in LUM. Alternatively, how can we explain the identification of other basins for which the simulations indicate flash flood susceptibility, but where no historical observations are present? If we trust in local observations on "non-affected" basins, provided by stakeholders or risk managers, 35 basins $(32 \%)$ have known local problems (flooded roads, small erosions) after intense rains. If we consider this additional information, the flash flood susceptibility is confirmed on 59 basins (57\% of the 148 studied basins). Finally, if the critical rain is recorded in the future, we should survey the basin reactivity and then see if the simulation results can be validated a posteriori. 

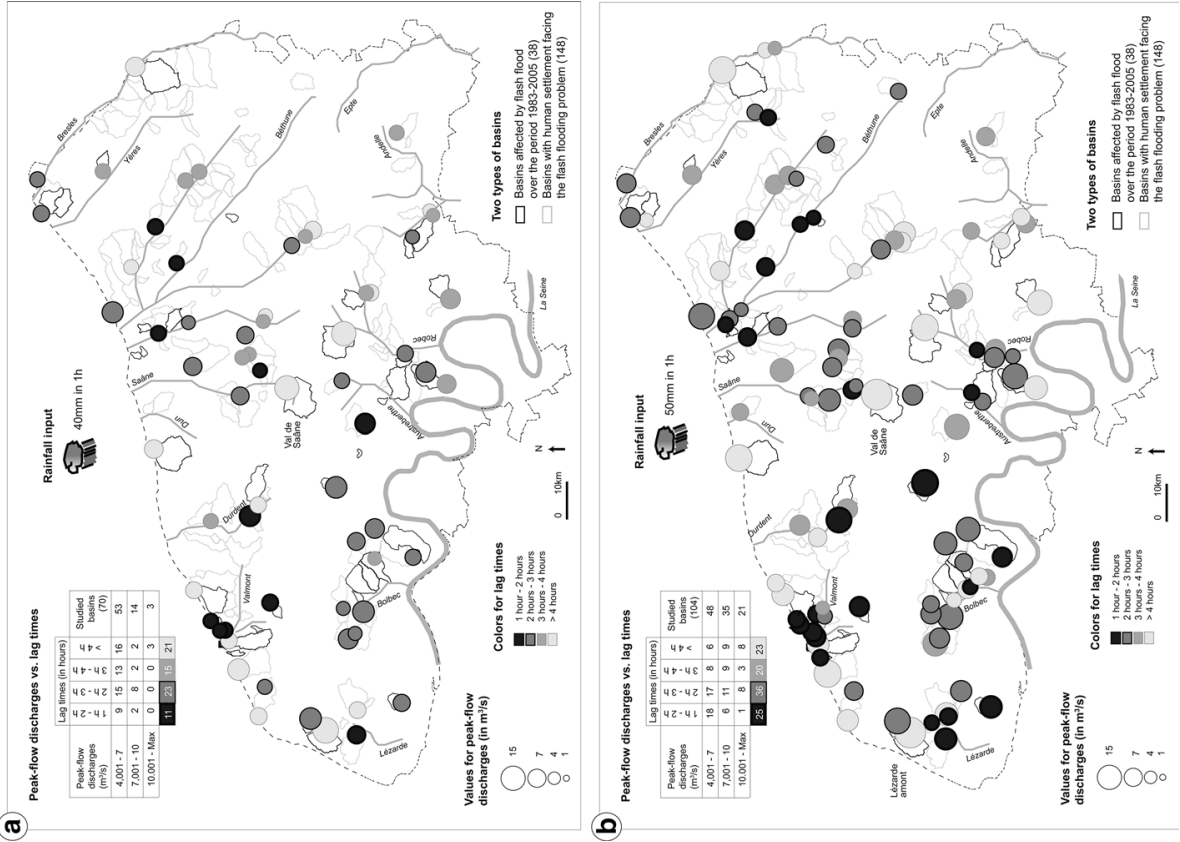

Fig. 7 Evolution of the lag times simulated by RUICELLS over the most sensitive basins (with peak discharges $>4 \mathrm{~m}^{3} / \mathrm{s}$ ) for storm events of $40 \mathrm{~mm}(\mathbf{a})$ and $50 \mathrm{~mm}(\mathbf{b})$ in $1 \mathrm{~h}$

\subsection{Advantages and limitations for anticipation}

Anticipation of flash floods in small basins becomes urgent, since they induce rare, violent and sudden impacts on inhabited outlets. Furthermore, the local population is unaware of the possible flash flooding risk to which they are exposed. The other models developed earlier, such as STREAM, LISEM, or WATEM (De Vente and Poesen 2005; Nearing et al. 2005), permit to manage flash flooding susceptibility for a specific basin but not on many basins, since local to outlet scales, and by playing with different intensities. Therefore, these simulations proposed by RUICELLS can improve our knowledge without taking into account rains frequency. This approach consists of combining the most recent and available GIS data with the CA modelling. Results are discussed with local stakeholders and risk managers to verify whether the highest simulated susceptibilities have resulted in previous problems. Simulations obtained in many basins are not validated but several experimentations in real time should be planned over the next 10 years. Nonetheless, these preliminary investigations give promising results. We hope that this kind of work will serve not only to help farmers reducing soil losses, but also to help forecasters to define places or roads where potential high-level damage can be expected. There is a need to protect people if time to react does not exceed a few minutes, as it was the case in the basin of Saint-Martin. We could also diffuse a vigilance signal with colors ranging from green to red, as it already exists in France for floods over greater basins (www.vigicrues.fr).

Similar investigations may be carried out in other sedimentary areas where the flash floods also occurred with violence in the last years, as in the Sussex (Boardman et al. 2003) or in Flanders (Evrard et al. 2007). Alternatively, these maps also question the networks 
capacities and the socio-economic stakes to face to flash flood events, and they also necessitate the study of resilience of societies and the evaluation of economic losses (Douvinet et al. 2013). For this, we have to quantify the precise structural vulnerability to flash floods at the inhabited outlets and the time needed for the restoration post-event. We will work on it with the SCHAPI (the French forecasting official service) over the period 2013-2016).

\section{Conclusion}

The anticipation of flash floods in small and dry basins located in the Seine-Maritime is hampered by a lack of hydrological, meteorological, and geomorphological knowledge. The rareness and severity of such events make the measurement of hydrological responses and behavior after intense rains difficult. In this paper, we present the methodological investigations and the flash flooding susceptibility results obtained on the entire department of Seine-Maritime using the CA RUICELLS model. We rely on the hydrological estimations (peak discharges, specific peak discharges and lag time) and the critical rains to identify conditions, at local scales, which may necessitate increasing vigilance from hydrological and meteorological forecasters (like for the FFG, Flash Flood Guidances, created in USA, Estupina-Borell et al. 2005). We emphasize the need for a careful interpretation of simulation results, remaining conscious of inherent assumptions of the model used and of the quality of input data. Even though the information on a number of documented flash flood events exist (Douvinet 2008), records for some susceptible areas are missing, which impedes the validation of a deterministic modelling approach, as adopted in this study. However, validations efforts could provide levels at which to issue alerts and question the potential effectiveness of a specific flash flood alert system for this region. And for this, field experiments and surveys are expected during the next 2 years.

Two main questions should be addressed in these subsequent studies. First, these floods are associated with high sediment concentrations that remain difficult to define. Indeed, managers and official services clean the flooded urbanized areas and erase deposits before they can be surveyed and studied. Thus, even though sediment sources are well known (soil erosion, destabilization of slopes and mass movements, incision in road networks, overthrusting of debris, vegetal, and artificial elements adding to solid fluxes), a precise quantification of the sediment budget is delicate in these small ungauged areas (Douvinet et al. 2013). Second, the lack of knowledge on specific stream powers (measured only in a few cross sections) and on influential factors (links between land use, morphological features, and rainfall intensities) for flash flooding requires additional studies. Indeed, a better assessment of the minimum values needed to induce erosion, incision, and flash flood should help us for a further understanding of the emergence of a turbid wave observed in several thalwegs.

Acknowledgments The authors are grateful to the Service Central d'Hydrométéorologie en Appui à la Prévision des Inondations (SCHAPI) for funding the RuRan project over the period 2011-2013 within which the study could be carried out. They also want to express their gratitude to the French Research Ministry and CNRS for funding the SYMBAD project (2004-2007), within which RUICELLS was developed and calibrated on a few basins. In addition, thanks are due to F. Mallet and A. Christol (for field experimentations and simulations), and to A. Escudier, B. Janet, A. Bachoc (SCHAPI), Y. Redor, K. Goncalvez (SPC$\mathrm{SACN}$ ) and P. Langlois (University of Rouen) for suggestions and comments, which helped to improve the quality of the article. 
Open Access This article is distributed under the terms of the Creative Commons Attribution License which permits any use, distribution, and reproduction in any medium, provided the original author(s) and the source are credited.

\section{References}

Anderson RS (1990) Eolian ripples as examples of self-organization in geomorphological systems. Earth-Sci Rev 29:77-96

Anquetin S, Ducrocq V, Braud I, Creutin JD (2009) Hydrometeorological modelling for flash flood areas. The case of the 2002 Gard event in France. Flood Risk Manag 2:101-110

Antoine JM, Desailly D, Gazelle F (2001) Les crues meurtrìres, du Roussillon aux Cévennes, Annales de Géographie, Editions Armand Colin, Paris, 110ème, 622:597-623

Arnaud-Fassetta G, Astrade L, Bardou E, Corbonnois J, Delahaye D, Fort M, Gautier E, Jacob N, Peiry J-L, Piégay H et Penven M-J (2011) Fluvial geomorphology and flood-risk management, Géomorphologie: relief, processus, environnement 2/2009. http://geomorphologie.revues.org/7554

Auzet AV, Boiffin J, Ludwig D (1995) Concentrated flow erosion in cultivated catchments: influence of soil surface state. Earth Surf Proc Land 20:759-767

Avolio MV, Crisci GM, Di Gregorio SD, Rongo R, Spataro W, Trunfio GA (2006) SCIARA $\gamma 2$ : an improved cellular automata model for lava flows and applications to the 2002 Etnean crisis. Comput Sci 32:876-889

Barrera A, Llasat MC, Barriendos M (2006) Estimation of extreme flash flood evolution in Barcelona county from 1351 to 2005. Nat Hazard Earth Syst Sci 6:505-518

Bécu N, Perez P, Walker A, Barreteau O, Le Page C (2003) Agent based simulation of a small catchment water management in northen thailand. Description of the catchscape model. Ecol Model 170:319-331

Begueria S (2006) Validation and evaluation of predictive models in hazard assessment and risk management. Nat Hazards 37:315-329

Benkhadra H (1997) Battance, ruissellement et érosion diffuse sur les sols limoneux cultivés. Déterminisme et transfert d'échelle de la parcelle au petit bassin versant. Thèse de Doctorat, Université d'Orléans, p 210

Boardman J, Evans R, Ford J (2003) Muddy floods on the South Downs, southern England: problem and responses. Environ Sci Policy 6:69-83

Bursik M, Martinez-Hackert B, Delgado H, Gonzalez-Huesca A (2003) A smoothed-particle hydrodynamic automaton of landform degradation by overland flow. Geomorphology 53:25-44

Cerdan O, Le Bissonnais Y, Couturier A, Bourennane H, Souchère V (2002) Rill erosion on cultivated hillslopes during two extreme rainfall events in Normandy, France. Soil Tillage Res 67:99-108

Clarke KC, Brass JA, Riggan PJ (1994) A cellular-automaton model of wildfire propagation and extinction. Photogramm Eng Remote Sensing 60(11):1355-1367

Collier CG, Fox NI (2003) Assessing the flooding susceptibility of river catchments to extreme rainfall in the United Kingdom. Int J River Basin Manag 1(3):1-11

Coulthard TJ, Van de Wiel MJ (2006) A cellular model of river meandering. Earth Surf Proc Land 31:123-132

Coulthard TJ, Hicks DM, Van de Wiel MJ (2007) Cellular modelling of river catchments and reaches: advantages, limitations and prospects. Geomorphology 90:192-207

Coulthard TJ, Neal JC, Bates PD, Ramiez J, De Ameira G, Hancock GR (2013) Integrating the LISFLOODFP-2D hydrodynamic model with the CAESAR model: implications for modelling landscape evolution. Earth Surf Proc Land 38:1897-1906

Cudennec C, Gogien F, Bourges J, Duchesne J, Kallel R (2002) Relative roles of geomorphology and water input distribution in an extreme flood structure. Publ IAHS 271:187-192

De Roo APJ (1999) LISFLOOD: a rainfall-runoff model for large river basins to assess the influence of land use changes on flood risk. In: Balabanis P et al (eds) Ribamod: river basin modelling, management and flood mitigation. Concerted Action, European Commission, EUR 18287 EN, pp 349-357

De Roo APJ, Wesseling CG, Ritsema CJ (1996) LISEM: a single-event physically based hydrological and soil model for drainage basins. I/Theory, input and output. Hydrol Process 10:1107-1117

De Vente J, Poesen J (2005) Predicting soil erosion and sediment yield at the basin scale: scale issues and semi-quantitative models. Earth Surf Rev 71:95-123

Dearing J, Plater A, Richmond N, Prandle D, Wolf J (2005) Towards high resolution cellular model for coastal simulation (CEMCOS). Tyndall Centre for Climate Change Research, Technical Report 26, p 71 
Delahaye D, Guermond Y, Langlois P (2001) Spatial interaction in the runoff process. Proceedings of the 12th ECTG2001, European Colloquium on Theoretical and Quantitative Geography, Saint-Valéry-enCaux, France, 2001, http://cybergeo.revues.org/3795

Devaud P (1995) L'érosion des sols dans le département de la Somme. Mémoire de DESS Environnement, aménagement, développement agricole. Agence de l'eau Artois-Picardie, p 102

DGPR (Direction Générale de la Prévention des Risques) (2011) Plan Submersions Rapides. Paris, p 256

Di Gregorio S, Serra R, Villani M (1998) Simulation of soil contamination and bioremediation by a cellular automaton model. Complex Syst 11(1):31-54

Dietrich WE, Wilson CJ, Montgomery DR, McKean J (1993) Analysis of erosion threshold, channel network and landscape morphology using a digital terrain model. J Geol 3:161-180

Douvinet J (2008) Les bassins versants sensibles aux « crues rapides » dans le Bassin parisien. Analyse de la structure et de la dynamique de systèmes spatiaux complexes. Thèse de doctorat en géographie, Université de Caen Basse-Normandie, p 381

Douvinet J, Delahaye D (2010) Caractéristiques des « crues rapides » du nord de la France (Bassin parisien) et risques asso- ciés. Géomorphologie: Relief, Environnement, Processus 1:73-90

Douvinet J, Delahaye D, Langlois P (2009) Use of geosimulations and of the complex system theory to better manage flash floods in the Paris Basin watersheds (France). Proceedings of the 3rd International Conference on Complex Systems and Applications (ICCSA'09), Le Havre, June 29-July 02, 2009

Douvinet J, Delahaye D, Langlois P (2013) Measuring surface flow concentrations using a cellular automaton metric: a new way of detecting the potential impacts of flash floods in sedimentary context. Géomorphologie, Relief, Environnement, Processus 1:27-46

Drogoul A (1993) De la simulation multi-agents à la résolution collective de problèmes. Thèse de doctorat en Informatique, Paris, p 230

Estupina-Borell V, Chorda J, Dartus D (2005) Prévision des crues éclair. Comptes Rendus Geosciences 337:1109-1119

Evrard O, Persoons E, Vandaele K, Van Wesemael B (2007) Effectiveness of erosion mitigation measures to prevent muddy floods: a case study in Belgium. Agric Ecosyst Environ 118:149-158

Favis-Mortlock D (1998) A self-organizing dynamic systems approach to the simulation of rill initiation and development on hillslopes. Comput Geosci 24:353-372

Ferraris L, Rudari R, Siccardi F (2002) The uncertainty in the prediction of flash floods in the northern mediterranean environment. J Hydrometerol 3:714-727

Fonstad M (2006) Cellular automata as analysis and synthesis engines at the geomorphology-ecology interface. Geomorphology 77:217-234

Gardner M (1970) The fantastic combinations of John Conway's new solitaire game of life. Sci Am 223(4): 120-123

Gaume E, Bain V, Bernardara P, Newinger O, Barbuc M, Bateman A, Blaskovicova L, Bloschl G, Borga M, Dumitrescu A, Daliakopoulos I, Garcia J, Irismescu A, Kohnova S, Koutroulis A, Marchi L, Matreat S, Medina V, Preciso E, Sempre-Torres D, Strancalie G, Szolgay J, Tsnais I, Velasco D, Viglione A (2009) A compilation of data on European flash floods. J Hydrol 367:70-78

Jaziri W (2004) Modélisation et gestion des contraintes pour un problème d'optimisation sur-contraint : application à l'aide à la décision pour la gestion du risque de ruissellement. Thèse de Géographie, Université de Rouen, p 230

Jetten V, Boiffin J, De Roo A (1996) Defining monitoring strategies for runoff and erosion studies in agricultural catchments: a simulation approach. EJSC 47(2):579-592

Joannon A (2004) Coordination spatiale des systèmes de culture pour la maîtrise de processus écologiques. Cas du ruissellement érosif dans les bassins versants agricoles du Pays de Caux, Haute- Normandie. Thèse de Doctorat à l'INA-PG, INRA SAD, 393 p. + annexes

Kappes MS, Malet J-P, Remaitre A, Horton P, Jaboyedoff M, Bell R (2011) Assessment of debris-flow susceptibility at medium-scale in the Barcelonnette Basin, France. Nat Hazard Earth Syst Sci 11:627-641

Kirkby MJ, Bracken LJ, Shannon J (2005) The influence of rainfall distribution and morphological factors on runoff delivery from dryland catchments in Spain. Catena 62:148-156

Lahousse P, Pierre G, Salvador P-G (2003) Contribution à la connaissance des vallons élémentaires du nord de la France: l'exemple de la creuse des fossés (Authieule, plateau picard). Quaternaire 14:189-196

Langlois P, Delahaye D (2002) « Ruicells », automate cellulaire pour la simulation du ruissellement de surface. Revue Internationale de Géomatique 12(4):461-487

Larue J-P (2005) The status of ravine-like incisions in the dry valleys of the Pays de Thelle (Paris basin, France). Geomorphology 68:242-256

Laurent F, Delclaux F, Graillot D (1998) Perte d'information lors de l'agrégation spatiale en hydrologie. Revue internationale de géomatique 8(1-2):99-119 
Lecomte V (1999) Transferts de produits phyto-sanitaires par le ruissellement et l'érosion de la parcelle au bassin versant. Processus, déterminisme et modélisation spatiale Thèse de Doctorat, INA- PG, 212 p. + annexes

Lumbroso D, Gaume E (2012) Reducing the uncertainty in indirect estimates of extreme flash flood discharges. J Hydrol 414:16-30

Mathieu R, King C, Le Bissonnais Y (1997) Contribution of multi-temporal SPOT data to the mapping of a soil erosion index. The case of loamy plateaux of northern France. Soil Technol 10:99-110

Masson F.X. (1987) L'érosion des terres agricoles dans la région du Nord-Pas-de-Calais. Terres et hommes du Nord 3:139-145

Ménard A, Marceau DJ (2006) Simulating the impact of forest management scenarios in an agricultural landscape of southern Quebec, Canada, using a cellular automata. Landsc Urban Plan 16:99-110

Merle J-P, Huet P, Martin X, Verrel J-L, Rat M, Boutin J-N, Bourget B, Varret J (2001) Inondations et coulées boueuses en Seine-Maritime. Proposition pour un plan d'action. Rapport de l'Inspection Générale de l'Environnement. Ministère de l'Aménagement du Territoire et de l'Aménagement, p 130

Mita D, Catsaros W, Gouranis N (2001) Runoff cascades, channel network and computation hierarchy determination on a structured semi-irregular triangular grid. J Hydrol 244:105-118

Morin E, Jacoby Y, Navon S, Bet-Halachmi E (2009) Towards flash flood prediction in the dry Dead Sea region utilizing radar rainfall information. Adv Water Resour 32:1066-1076

Moussa R, Bocquillon C (1996) Fractal analysis of tree-like channel networks from digital elevation model data. J Hydrol 187:157-172

Murray AB, Paola C (1994) A cellular model of braided rivers. Nature 371:54-57

Nearing MA, Jetten V, Baffaut C, Cerdan O, Couturier A, Hernandez M, Le Bissonnais Y, Nichols MH, Nunes NJ, Renschler CS, Souchere V, Van Oost K (2005) Modelling response of soil erosion and runoff to changes in precipitation and land cover. Catena 61:131-154

O'Callaghan JF, Mark DM (1984) The extraction of drainage networks from digital elevation map. Comput Vis Graph Image Process 28:323-344

Ortega JE, Heydt GG (2009) Geomorphological and sedi- mentological analysis of flash floods deposits. The case of the 1997 Rivillas flood (Spain). Geomorphology 112:1-14

Palacios-Vélez OL, Gandoy-Bernasconi W, Cuevas-Renaud B (1998) Analysis of surface runoff and the computation order of unit elements in distributed hydrological models. J Hydrol 211:266-274

Parsons JA, Fonstad MA (2007) A cellular automata model of surface water flow. Hydrol Process 21(16):2189-2195

Phipps M, Langlois P (1997) Automates cellulaires- Application à la simulation urbaine, Editions Hermès, Collection sciences, Paris, p 208

Reid I (2004) - Flash flood. In: Goudie A (ed) Encyclopedia of geomorphology. Routledge, London, p 1156

Renard B, Kochanek K, Lang M, Garavaglia F, Paquet E, Neppel L, Najib K, Carreau J, Arnaud P, Aubert Y, Borchi F, Jourdain J-M, Veysseire JM, Sauquet E, Auffray A (2013) Data-based comparison of frequency analysis methods for extremes: a general framework. Water Resour Res 49:1-19

Rodriguez-Iturbe I, Rinaldo A (1997) Fractal River Basins, chance and self-organization. Cambridge University Press, Cambridge, p 547

Ruin I, Gaillard J-C, Lutoff C (2007) How to get there? Assessing motorists' flash flood risk perception on daily itineraries. Environ Hazards 7(3):235-244

Schmitz GH, Cullmann J (2008) PAI-OFF: a new proposal for online flood forecasting in flash flood prone catchments. J Hydrol 360:1-14

Strahler A-N (1952) Hypsometric (area-altitude) analysis of erosional topography. Bull Geol Soc America 63(11):1117-1142

Souchère V, Cerdan O, Dubreuil N, Le Bissonnais Y, King C (2005) Modelling impact of agri-environmental scenarios on runoff in a cultivated catchment (Normandy, France). Catena 61:229-240

Tarboton DG (1997) A new method for the determination of flow directions and upslope areas in grid digital elevation models. Water Resour Res 33:309-319

Teles V, De Marsily G, Perrier E (1998) Sur une nouvelle approche de modélisation de la mise en place des sédiments dans une plaine alluviale pour en représenter l'hétérogénéité. Compte-rendus de l'Académie des Sciences 327:597-606

Thomas N, Nicholas AP (2002) Simulation of braided river flow using a new cellular routing scheme. Geomorphology 43:179-195

Tucker GE, Catani F, Rinaldo A, Bras RL (2001) Statistical analysis of drainage density from digital terrain. Geomorphology 36:187-202

Valette G, Prévost S, Lucas L, Léonard J (2006) SoDA Project: a simulation of surface soil degradation by rainfall. Comput Graph 30:494-506 
Van De Wiel MJ, Coulthard TJ, Macklin MG, Lewin J (2007) Embedding reach-scale fluvial dynamics within the CAESAR cellular automaton landscape evolution model. Geomorphology 90:283-301

Van de Wiel MJ, Coulthard TJ, Macklin MG, Lewin J (2011) Modelling the response of river systems to environmental change: progress, problems and prospects for palaeo-environmental reconstructions. Earth Sci Rev 104:167-185 (ISSN 0012-8252)

Veltri M, Veltri P, Maiolo M (1996) On the fractal dimension of natural channel network. J Hydrol $187: 137-144$

Vogt JV, Colombo R, Bertolo F (2003) Deriving drainage network and catchments boundaries as a new methodology combining digital elevation data and environmental characteristics. Geomorphology 53:281-298

Wolfram S (2002) A new kind of science. Wolfram Media, Inc., p 1197 